\title{
The Relationship between Dividend Payout and Firm Financial Performance: A Study of Botswana Listed Companies
}

\author{
Simangaliso Biza-Khupe, Ph.D \\ Department of Accounting and Finance \\ University of Botswana, P.O. Box 70117, Gaborone, Botswana
}

Amogelang Themba

Department of Accounting and Finance

University of Botswana

\begin{abstract}
The association between dividend payout and the financial performance of a firm has been a subject of debate among scholars for decades. This debate has been particularly fueled and prolonged by the ambiguity of the results of prior research on the association between the two variables and the broadness in perspective of the extant literature on the subject matter. This research seeks to further explore this subject matter specifically by testing the relationship between dividend payout and firm financial performance within the context of Botswana listed firms. The model used in the paper incorporates net profits, systematic risk and total assets as the main variables. The regression analysis results found a positive correlation between dividend payout and firm profitability. The association of the variables of systematic risk and total assets to dividend payout was not supported statistically. To the extent that the paper found a statistically significant relationship between dividend payout and NOPAT, the relevance of dividend policy was affirmed, a matter that has implications on companies' financial and operational strategies.
\end{abstract}

Keywords: Dividend payout; financial performance; Systematic risk; Total assets; Net Operating Profit after Tax (NOPAT)

\section{INTRODUCTION}

Dividends are regarded as benefits that accrue to shareholders in return for investing and taking a risk in a business venture [1]. A firm's dividend policy provides the necessary parameters, restraints and guidelines on how a firm ought to divide its net earnings between retained earnings and dividend payouts in order to optimize its value. The literature identifies a myriad of factors that are taken into account in determining a dividend policy, among them: firm's financial limitations (e.g. liquidity constraints), available investment opportunities, financing opportunities, quantities of required funds, expectations of stakeholders, firm size, and provisions of the law $[1,2]$. Evidently, dividend policy is core to a strand of financial and managerial strategies that would effectively determine firms' long term sustainability as going concerns.

It is a widely held view that the primary objective of a firm is to maximize shareholders' wealth principally by optimizing a firm's share price. Investment decisions, financing decisions and dividend decisions have been singled out as three types of decisions that have the potential to have a sizeable impact on the value of a firm. The decision on the ratio used to allocate net earnings between dividend payout and retained earnings has far reaching implications on the 
firm's financial standing and, hence, operational capacity, e.g. capital structure; the weighted average cost of capital (WACC); liquidity; internal rate of return (IRR) and; financial risk. The ripple-effect of all of these elements cascades to literally most of the operational centres of any organization, and such is the importance of dividend policy.

Several other explanations for the existence and importance of dividend policy have been suggested over the decades. For example, while some scholars have viewed dividends as the source of cash flow to the shareholders, others have suggested that dividends are an intricate component of signalling information relating to firm's current and future performance, as posited by the signalling hypothesis [2]. Stacescu [3] alluded that empirical studies have generally found that an increase in dividend payouts by a firm is considered good news by investors, while a decrease leads to a negative market reaction. Based on the premise that the primary objective of a firm is to maximise shareholders' wealth, it would be reasonable to presuppose that management would be keen on a positive, rather than negative, market reaction [4].

While the arguments for the importance and pivotal role of dividend policy on a firm's wellbeing as a going concern are coherent and sound, the true nature of the relationship between dividend policy and a firm's financial performance is less obvious. This subject matter has remained contentious for decades. While vast literature exists on the relationship between dividend policy and financial performance, empirical results have largely been inconclusive.

Arguably, the most influential work on the relationship between dividend policy and firm's financial performance was the seminal paper by Miller and Modigliani [5] which argued that the payout decision is irrelevant to a firm's financial performance because it neither creates nor destroys value for shareholders. In this regard, dividend policy was rendered both irrelevant and inconsequential. Under the presumed conditions of perfect markets, it was advanced that the value of any asset is derived from real economic considerations (earnings and investments) and not the manner in which the returns from assets are packaged between dividends and capital gains. While, from a practical perspective, the arguments of the Dividend Irrelevance Theory are fraught with limitations, they formed the backbone of the modern dividend theories, e.g.; bird-in-hand theory, clientele effect; signalling hypothesis; agency theory.

In a quest to test the myriad of hypotheses suggested by these theories, a number of variables have been used to proxy financial performance (i.e. earnings, stock repurchases, revenue and firm size) in establishing its relationship with dividend payout. Systematic risk, as a control variable, has generally not been a variable for consideration in many of the previous studies. Grullon, Michaely [6] opined that the alternative investors' interpretation of a firm's dividend increase as good cash flow prospects is favourable systematic risk. Intuitively, and therefore, systematic risk is an integral part of dividend policy determination and firm's financial performance.

It is on the backdrop of the importance of dividend policy to firms' financial performance, the ambiguity of empirical evidence on the subject matter and the general disregard for systemic risk in prior studies that forms the premise for this research. The objective of the paper is to explore the relationship between dividend payout and firms' profitability (hypothesized to proxy financial performance) in Botswana publicly listed companies. The proposed theoretical framework accounts for systematic risk, as suggested by Grullon, Michaely [6]. 


\section{LITERATURE OVERVIEW}

Numerous studies have been conducted on the relationship between dividend payout and firms' financial performance across different countries, different continents and on economies at different developmental levels. The literature that is replete with studies on this phenomenon is in concert on the importance of the subject matter and its potential impact on the long term financial well-being of any business entity. However, empirical evidence on the true nature of the relationship between dividend policy and a firms' financial performance remains conflicted and ambiguous, a matter which always throws the dividend relevance hypothesis into the spotlight.

Uwuigbe, Jafaru [4] conducted a study on the relationship between dividend payout and firm financial performance in the Nairobi Securities Exchange. The study used regression analysis to test for this relationship, where dividend payout was measured by the actual dividends paid and firm financial performance measured by the net operating profit after tax (NOPAT). Other variables incorporated into the theoretical framework were firm size (measured by total assets) and revenue. The results showed dividend payout, firm size and revenue to have a positive relationship with net earnings (firms' financial performance). In conclusion, the paper did support the dividend relevance hypothesis and suggested that managers should devote much time to design a dividend policy that will enhance firms' performance in this context. The approach used in this study, and other similar studies, has drawn some criticism. The criticism stems from the viewpoint that these studies did not incorporate future revenues in the function, and thereby ignoring the signalling theory notion that dividends can be used as a costly means to signal future profitability [3]. Grullon, Michaely [6] asserted that rather than an increase in profitability, dividend increases could reflect a decrease in risk in accordance to the 'maturity hypotheses. A similar study was done to determine the relationship between dividends payout and firm's performance in Nigeria using a sample of 50 companies listed in the Nigerian Stock Exchange [7]. Using regression analysis, the results showed a positive association between the financial performance of firms and dividend payout. Other independent variables like firm size, ownership structure and return on equity where taken as affecting the overall profitability of firms. In this study, firm size was incorporated as a variable affecting dividends payout.

A study by Ajanthan [2] underpinned the dividend relevance hypothesis. The study was conducted on hotels and restaurant companies listed in the Colombo Stock Exchange. Using regression and correlation analysis, the results indicated a positive relationship between firm's profitability and dividends payout. The theoretical framework adopted also incorporated firms' total assets and revenues as independent variables impacting profitability. The study concluded that dividend policy was relevant to optimising profitability levels and hence managers should consciously and accordingly craft dividend policies. However, as with Uwuigbe, Jafaru [4], the paper used current earnings rather than forecasted earnings. Nissim and Ziv [1] argued that to effectively investigate whether dividend changes convey new information about future profitability, one has to estimate expected profitability.

There are a host of studies that have conjectured and empirically supported the dividend relevance hypothesis, for example [2, 7, and 8]. Skinne [9], however, argued from a slightly different dimension of the substitution effect of dividends payout by stock repurchases. The study examined the extent to which the relationship between earnings and corporate payout policy has changed over the last 50 years. The study found a trend of two corporate payout emerging in the 1980s: firms that both paid dividends and made stock repurchases and firms that only made stock repurchases. For firms that both paid dividends and made repurchases, managers were found to increasingly coordinate dividend and repurchase decisions in a way 
that maps total payouts of earnings. In the study, there was an observed increase in managers' use of stock repurchases to payout earnings that was accompanied by a tendency towards curtailment of cash dividend payouts. If the two observations are not read in tandem, they would give the false conclusion of a conservative dividend policy approach. This dimension serves to demonstrate on the complexities and intricacies of dividend policy, a matter that has implications on the interpretation of the results on many past and present studies in the subject matter.

Nissim and Ziv [1] conducted one of the most extensive and robust studies on the relationship between dividend payout and expected firm's profitability. Supporting the informational content hypothesis of dividends, the study found that changes in dividend payouts transimitted some information about profitability performamce in subsequent years. The study projected that changes in dividend payouts are positively related to changes in earnings in each of the two years subsequent to the change in dividend payout. The study adopted a modified regression model with relation to the estimation of unexpected earnings, measurement error and omitted correlated variables. Nissim and Ziv [1] argued that previous studies failed to uncover the true relation between dividends and future earnings because researchers used the wrong model to control for the expected changes in earnings. Specifically, it was argued that when using regression analysis that controls for a particular (linear) form of mean reversion in earnings, dividend changes are positively correlated with future earnings changes. With the modified model, it was demonstrated that current dividend changes are positively associated with future prospective earnings, a novel concept. Grullon, Michaely [6] also conducted a research on changes of dividends payout, but as an indicator of firms' maturity. The objective was to use the findings to understand the informational content of changes in dividend payouts. The study postulated that firms which decrease dividends payouts would experience significant growth in future earnings. The study also examined the relationship between changes in dividends and changes in systematic risk of a firm, wherein systematic risk was measured using the Fama and French [10] three-factor model. It was found that dividendincreasing firms had an average market beta that was slightly above one (1.09), and dividenddecreasing firms had an average market beta that was slightly below one (0.93). In this regard, the study empirically demonstrated the relation between dividend payout and firms' systematic risk.

Finally, and contrary to studies discussed thus far, there are many other strands of the literature that have empirically supported variations of the notion of the relevance of dividends to firms' financial performance and the dividend irrelevance hypothesis. Mozes, Donna [11] conducted a study of 681 firms on the relationship between dividends payout and corporations' earnings. Using a regressional model, the results indicated that large dividend increases are associated with a decline in the firms' future performance, and the reverse held true with small increase in dividends. In a different study, Robert, Arnott [12] used the free cash-flow theory to test for how low dividend payouts impact firms' growth. The study concluded that growth that is associated with low dividend payouts could be a direct result of suboptimal investment decisions and less than ideal projects engagements by managers with excess free cash flows at their disposal. In contrast, Farsio, Geary [13] found no significant relationship between dividends payout and firm's performance in the long-run and concluded that studies that support the relevance theory are based on short-term periods and hence misleading to investors. There are other studies that have empirically supported the dividend irrelevance hypothesis, for example, [5, 11, 13, and 14]. 
The complexities of dividend policy research are apparent and the inconclusiveness of the results from prior studies has only deepened the debate. Notwithstanding the above, the importance of dividend policy in the corporate world is undisputed. Truly, dividend policy shall remain "...a puzzle, with pieces that just do not fit together" [15]. Noteworthy is that prior studies have not been without limitations, and particularly criticised for not accounting for the mean reversion of earnings [16] and also for generally ignoring the systematic risk effect on dividend payout [14]. It is the objective of this study to address these concerns. The secondary objective of the paper is to examine the relationship between dividend payout and firm's financial performance as it prevails in the Botswana capital market.

Cognisant of the weight, both theoretically and empirically, of the dividend relevance paradigm, and informed by the significance of the strides that firms take in establishing firms' dividend policies, this paper posits that dividend policy impacts on a firms financial performance and hence the prospective to influence firms' value. Specifically, and from the premise of the signalling hypothesis, a positive relationship between dividends payout and future profits is posited. Basically, changes in dividend payouts are construed to transmit information about prospective future profitability levels of a firm. Also, the literature posits a negative relationship between dividend payout and systematic risk $[1,2,6,10,14,17]$. It is thus hypothesised that:

H1 Dividend payout is positively related to financial performance of a firm

H2 Dividend payout is negatively related to systematic risk of a firm

H3 Dividend payout is positively related to firm size

\section{DATA ANALYSIS AND RESULTS}

Measures used in the paper were predominantly adopted from the extant literature and adapted to the study. Dividend Payout was measured by the actual dividends paid and firm financial performance was measured by Net Operating Profit after Tax (NOPAT) [2, 4]. Total assets were used as a proxy for firm Size [7]. The data used covered a five-year span.

The research targeted firms listed in the Botswana Stock Exchange (BSE) that had an uninterrupted listing in the material period. The readily availability of their full financial statements over the material period was another factor for consideration. Further, a company should have paid some ordinary share dividends in the course of the targeted period. After the necessary screening process of all companies listed in the BSE, a sample size of twelve firms was obtained out of a total of 24 listed domestic companies. Sample consisted of firms from diverse industries and sectors including financial services, retail, property development and management. Annual financial reports of these firms were either accessed online from the respective firm websites or hardcopies directly obtained from the firms' offices or the BSE. These reports were duly audited and available in the public domain.

Correlation and multiple regression analytical techniques were used to analyse the data, in line with most of the prior studies conducted in this field of research. The multiple regression function used is given below and the key variables provided in Table 1.

$\mathrm{DIVP}=\alpha 0+\alpha 1 \mathrm{NOPAT}+\alpha 2 \beta \mathrm{i}+\alpha 3 \mathrm{TA}$ 
Table 1: Key Variables

\begin{tabular}{|l|l|}
\hline \multicolumn{2}{|l|}{ Dependent Variable } \\
\hline Dividend Payout (DIVP) & $=$ Total Dividends Paid during the Period \\
\hline Independent Variable & $=$ Net Operating Profit After Tax \\
\hline Profits (NOPAT) & $=$ The stock's Total Risk \\
\hline Control Variables & $=$ Amount of Total Assets \\
\hline Stock Beta (Bi) & \\
\hline Total Assets (TA) &
\end{tabular}

As a caveat and owing to the small number of firms listed in the BSE, the sample size was small by default. Admittedly, the achieved sample size is not ideal for the correlation and regression analysis, a matter that impacts the results. In this regard, and for all intents and purposes, the study should be considered exploratory and the findings interpreted in this light. The descriptive statistics for the key variables are presented in Table 2.

\section{Table 2: Descriptive Statistics}

\begin{tabular}{lllllll} 
& \multicolumn{1}{c}{ Mean } & Median & Maximum & Minimum & Skewness & Kurtosis \\
\hline DIVP (P'000) & 74194.24 & 30127.69 & 589651 & 0 & 2.6 & 10.62 \\
TA (P'000) & 4095798.71 & 480390.22 & 30167813 & 352.218 & 1.95 & 3.09 \\
$\begin{array}{l}\text { NOPAT } \\
\left(P^{\prime} 000\right)\end{array}$ & 129695.62 & 84382.5 & 572918 & -3467.94 & 1.46 & 1.85 \\
$\beta I(100$ b.p) & 1700.17 & 1565.5 & 6789 & 15 & 1.35 & 3.23 \\
\hline
\end{tabular}

Measurers of variability and central tendency are presented in table 2 above, the findings as shown above present a mean dividend pay-out of about P74 million (US\$7.05m) for the firms under consideration. On the other hand; total assets and profits averaged P4 billion (US\$380m) and P129 million (US $\$ 12.29 \mathrm{~m}$ ) respectively. The table also shows that dividend payout, total assets and systematic have a Leptokurtic distribution given by Kurtosis $>3$, which defines the probability distribution as sharper than a normal distribution, with values concentrated around the mean and this means high probability for extreme values, this is with an exception to NOPAT as they show a Platykurtic distribution of Kurtosis $<3$.

Regression analysis of the data was performed and the results are presented in Table 3 . The dependent variable for the regression equation was the Dividend Payout, while the independent variables were NOPAT, Systematic Risk and Total Asset, and the resulting regression model to estimate Dividend Payout was:

DIVP $=-2932.11+0.57 \mathrm{NOPAT}+0.34 \beta \mathrm{i}+0.00 \mathrm{TA}$

Table 3: Results Summary

\begin{tabular}{llll}
\hline & Coefficients & P-value & Adjusted \\
& & & R Square \\
Intercept & -2932.11 & 0.86 & \\
TA & 0 & 0.85 & 0.6 \\
NOPAT & 0.57 & 0 & \\
$\beta i$ & 0.34 & 0.72 & \\
\hline
\end{tabular}

It was the objective of this paper to explore the relationship between dividend payout and firm's profitability hypothesized to proxy financial performance, with total assets and systematic risk as control variables to the regression model. The regression model yielded an adjusted R square value of $60 \%$. A summary of the test results and the research findings are next discussed. 
Hypothesis 1 proposed that dividend payout is positively related to financial performance of a firm as measured by its profitability (NOPAT). The results indicated a standardised regression path coefficient of 0.57 with a p-value of 0.00 that was statistically significant at $p<0.05$. The hypothesis was therefore supported.

The findings support the classical school of thought which postulates that dividend payout is relevant to a firm's financial performance. Thus, the findings suggested that managers should devote much time to design a dividend policy that will enhance firm's performance [4]. Hence changes in dividend pay-outs are construed to transmit information about prospective future profitability levels of a firm.

Hypothesis 2 proposed that dividend payout is negatively related to systematic risk of a firm. The results indicated a standardised regression path coefficient of 0.34 with a p-value of 0.72 that was not statistically significant at $\mathrm{p}>0.05$. The hypothesis was therefore not supported.

The findings contradict such other studies as Grullon, Michaely [6] which found negative correlation association between the two variables. Essentially, this an area for future research, particularly considering the pivotal role that systematic risk plays in signaling theory.

Hypothesis 3 proposed that dividend payout is positively related to firm size as measured by firms' total assets. The results indicated a standardised regression path coefficient with an associated $p$-value of 0.85 that was not statistically significant at $p>0.05$. The hypothesis was therefore not supported.

The findings are suggestive that firm size is not a factor to reckon with in dividend payout policy. Other studies have used different proxies to measure firm size, i.e. Uwuigbe, Jafaru [7] used the number of directors and found a significant relationship between firm size and dividend payout of listed firms in Nigeria.

\section{CONCLUSION}

The study delved into the relationship between dividend payout and firm financial performance in Botswana Stock Exchange listed companies. The study was particularly motivated by the importance of the subject matter, the ambiguity of empirical evidence presented in previous studies and the general disregard for systemic risk in prior studies. The BSE is a relatively small stock exchange and the sample size will always be small by default. These are less than ideal conditions for correlation or regression analysis, a matter that may have impacted the study results. In general, the results were suggestive of a positive relationship between NOPAT and dividend payout. These findings affirm the relevance of dividend policy, an issue that has implications on companies' financial and operational strategies. Evidently, managers should devote much time to design a dividend policy that will maximise shareholders wealth. The intricacies of dividend policy are not easy to disentangle. To the extent that there are other extensions to dividend policy, such as stock repurchases, complicates exacerbate the already complex subject matter. The study concluded that dividend policy was relevant to optimising profitability levels and hence managers should consciously and accordingly craft dividend policies.

Beyond the complexities of the subject matter is also the myriad of other factors identified by the literature as key. Total assets, size, systematic risk, ownership structure, tax policies, financial leverage and capital structure are some of the examples of factors that impact dividend payout. While this study did not find statistical significant relationships as relating to these other factors (total assets and systematic risk), it does not discount their importance. It is 
only through increased understanding through further research that the illusive consensus can be reached among scholars and between scholars and practitioners.

\section{References}

1. Nissim, D. and A. Ziv, Dividend Changes and Future Profitability. The Journal of Finance, 2001. 56: p. 2111-2133.

2. Ajanthan, A., the Relationship between Dividend Payout and Firm Profitability: A Study of Listed Hotels and Restaurant Companies in Sri Lanka. International Journal of Scientific and Research 2013. 3(6): p. 16.

3. Stacescu, B., Dividend policy in Switzerland Financial Markets and Portfolio Management, 2006. 20(2): p. 153-183.

4. Uwuigbe, U., J. Jafaru, and A. Ajayi, the Relationship between Dividend Payout and Firm Performance: A Study of Listed Companies in Kenya. European Scientific Journal, 2012. 8(9): p. 1857 - 7881.

5. Miller, M.H. and F. Modigliani, Dividend Policy, Growth, and the Valuation of Shares. The Journal of Business, 1961. 34(4): p. 411-433.

6. Grullon, G., R. Michaely, and B. Swaminathan, Are Dividend Changes a Sign of Firm Maturity? The Journal of Business, 2002. 75(3): p. 387-424.

7. Uwuigbe, U., J. Jafaru, and A. Ajayi, Dividend Policy and Firm Performance: A Study of Listed Firms in Nigeria. Accounting and Management Information Systems, 2012. 11(3): p. 442-454.

8. Kao, C.T. and C. Wu, Tests of Dividend Signaling Using the Marsh-Merton Model: A Generalized Friction Approach. The Journal of Business, 1994. 67(1): p. 45-68

9. Skinne, D.J., The Evolving Relation between Earnings, Dividends, and Stock Repurchases. Journal of Financial Economics, 2008. 87(3): p. 582-609.

10. Fama, E.F. and K.R. French, Taxes, Financing Decisions and Firm Value. The Journal of Finance, 1998. 53(3): p. 819-843.

11. Mozes, H.A., C. Donna, and D.C. Rapaccioli, the Link between Dividend Changes and Future Earnings. Journal of Financial Statement Analysis, 1998. 3(3): p. 29-39.

12. Robert, D., R.D. Arnott, and C.S. Asness, Surprise! Higher Dividends = Higher Earnings Growth. Financial Analyst Journal, 2003. January/February: p. 70-85.

13. Farsio, F., A. Geary, and J. Moser, the Relationship between Dividends and Earnings. Journal for Economic Educators, 2004. 4(4): p. 1-5.

14. Grullon, G., et al., Dividend Changes Do Not Signal Changes in Future Profitability. Journal of Business, 2005. 78(5): p. 1659-1682.

15. Black, F., The Dividend Puzzle. The Journal of Portfolio Management, 1976. 2(2): p. 5-8.

16. Fama, E.F. and K.R. French, Forecasting Profitability and Earnings. The Journal of Business, 2000. 73(2): p. 161-175.

17. Amidu, M., How Does Dividend Policy Affect Performance of the Firm on Ghana Stock Exchange? Investment Management and Financial Innovations, 2007. 4(2): p. 103-112 